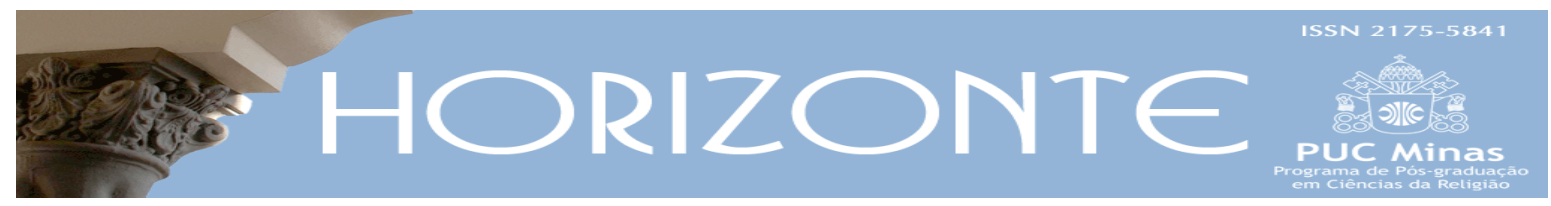

Dossiê: Narrativas Sagradas e Linguagens Religiosas - Artigo Original (c) (i)

DOI - 10.5752/P.2175-5841.2016v14n42p262

\title{
Narrativas Apócrifas e Linguagem Religiosa como memória e sentidos das comunidades cristãs primitivas, pela égide das teorias da linguagem
}

\author{
Apocryphal narratives and Religious Language as memory and meanings of \\ the early Christian communities by the aegis of language theories
}

José Luiz Izidoro*

\section{Resumo}

\begin{abstract}
Os conceitos concebidos das Teorias da Linguagem tornam-se um material pedagógico e metodológico de fundamental importância para a análise da narrativa sagrada, onde o texto poderá ser interpretado e compreendido com outros significados e sentidos, a partir das diferentes experiências individuais e coletivas dos grupos religiosos cristãos, incorporados no exercício de memórias e na reelaboração de novas narrativas e que possibilitará a formação e a preservação das identidades socioculturais e religiosas. $O$ estudo dos textos apócrifos se torna uma valiosa ferramenta metodológica de profunda relevância para a pesquisa do Cristianismo primitivo, definido e incorporado no conjunto das diferentes metodologias com força de equivalência e de complementaridade, firmado pelo seu caráter literário de gênero exótico e de diferenciação. É nessa perspectiva que aqui abordaremos a obra de Atos Apócrifos de André como contribuição para a pesquisa do Cristianismo primitivo e como forte expressão da construção das diferentes formas de linguagens religiosas.
\end{abstract}

Palavras-chave: Linguagem; Religião; Cultura; Memória; Ficção.

\begin{abstract}
The concepts of language theories become an educational and methodological materials of fundamental importance to the analysis of the sacred narrative, where the text can be interpreted and understood with other meanings and senses, from the different individual and collective experiences of the groups religious Christian, incorporated in the exercise of memories and re-elaboration of new narratives and that will enable the formation and preservation of religious socio-cultural identities. The study of apocryphal texts becomes a valuable methodological tool of profound relevance to the research of Early Christianity, defined and incorporated in the group of the different methodologies with power equivalence and complementarity, consolidated by its literary character of exotic genre and differentiation. It is in this perspective that we discuss here the work of Apocrypha Acts of Andrew, as a contribution to the research of Early Christianity $y$ when expression strong of the construction of the forms different of religious language.
\end{abstract}

Keywords: Language; Religion; Culture; Memory; Fiction.

Artigo recebido em 27 de maio de 2015 e aprovado em 30 de maio de 2016.

* Doutor e Pós-doutor em Ciências da Religião (UMESP), Professor de Filosofia, Teologia e Antropologia no Centro de Ensino Superior de Juiz de Fora - CES. País de origem: Brasil. E-mail: jeso_nuap@hotmail.com

Horizonte, Belo Horizonte, v. 14, n. 42, p. 262-283, abr./jun. 2016 - ISSN 2175-5841 


\section{Introdução}

A história do Cristianismo primitivo não pode ser inferida dos "fatos empiricamente comprováveis”, de acordo com o rigor metódico empírico. Nesse sentido, se enlaçam as disciplinas no empreendimento das sondagens dos fatos e dos acontecimentos, mas na perspectiva dos sentidos e dos diferentes significados que gerarão as narrativas e os textos, sempre suscetíveis de diferentes interpretações. Desse modo, se exige uma compreensão do conceito de história como uma narrativa de sucessos e não uma demonstração descritiva dos fatos empiricamente comprovados.

A historiografia, pois, não é descritiva, mas reconstrutiva. Ela não alinha os fatos nus, mas unicamente unifica fatos interpretados em função de uma lógica estabelecida pelo historiador. A veracidade, pois, da história não depende da realidade em si, do acontecimento relatado; ela depende da interpretação que ele dá de uma realidade, sempre suscetível, em si, de uma pluralidade de opções interpretativas (MARGUERAT, 2003, p.18).

É nessa perspectiva que situamos o "grande leque de experiências cristãs no período do Cristianismo primitivo" através da vasta literatura e interpretações que emergem nesses períodos. Assim, “o cristianismo primitivo produziu um grande caudal de literatura própria que serviu para propagar por diversas vias a fé cristã" (VIELHAUER, 1991, p. 811). São experiências cristãs primitivas consideradas como células de um cristianismo germinal que, passando pela oralidade, irá fazer parte da vasta literatura intertestamentária. Assim, consideramos nesse vasto caudal da literatura cristã as obras denominadas apócrifas e gnósticas, que muito contribuem para uma aproximação às origens do Cristianismo primitivo. ${ }^{1}$

\footnotetext{
${ }^{1}$ Participei do V Congresso da ANPTECRE que se realizou em Curitiba nos dias 09, 10 e 11 de setembro de 2015, com o tema "Religião, Direitos Humanos e Laicidades". O GT 02 teve como temática "Religião como texto: Linguagem e Produção de Sentido", onde tive a oportunidade de apresentar uma breve Comunicação científica com o título "Linguagem e Literatura Sagrada como Memória e Sentidos das Comunidades Cristãs Primitivas", como discussão preliminar do estado atual da questão a respeito do tema, o qual eu estava desenvolvendo na minha pesquisa de pós-doutorado. Esses trabalhos de pesquisa acadêmica me motivaram na escolha do tema "Narrativas apócrifas e Linguagem religiosa como memória e sentidos das Comunidades Cristãs Primitivas, pela égide das Teorias da Linguagem".
}

Horizonte, Belo Horizonte, v. 14, n. 42, p. 262-283, abr./jun. 2016 - ISSN 2175-5841 
Para Schneemelcher (1991, p. 9), “o conceito ‘Novo Testamento apócrifo’ é provavelmente formado por analogia ao "Velho Testamento apócrifo", o que torna difícil definir exatamente o conceito do "Novo Testamento apócrifo". Consequentemente, faz-se necessário distinguir este de outras formas como um gênero especial da literatura em termos de forma e conteúdo, clarificando, portanto, os que frequentemente são usados sem exatidão. Dessa forma, continua Schneemelcher (1991, p. 9), não se pode definir o conceito "Novo Testamento apócrifo”, desde seu conteúdo, como escritos que não foram aceitáveis no cânon. Ambos são considerados trabalhos variados e heterogêneos. Porém, para uma melhor compreensão da literatura apócrifa neotestamentária, é importante manter a conexão entre esta e os listados no cânon. A ordem "Evangelhos, Cartas, Atos dos Apóstolos e Apocalipse não é uma organização apócrifa com craves canônica, e sim uma hipótese de trabalho prático para facilitar a compreensão de tão complexa literatura” (SCHNEEMELCHER, 1991, p. 61).

\section{Matizes extrabíblicos}

Para Helmut Köester (1988, p. 508-511), os escritos não canônicos do Cristianismo primitivo distribuem-se nos dos Padres apostólicos, nas coleções maniqueias e gnósticas, nos apócrifos e nos escassos testemunhos não cristãos. Descrevendo com parcos detalhes os escritos não canônicos, Köester faz as seguintes considerações: no que se refere aos Padres apostólicos, considera que, junto aos escritos canônicos neotestamentários, surgiram outros escritos e coleções de textos que compreendem em parte obras reconhecidas e utilizadas na Antiguidade por escritores eclesiásticos. Também partes dessas obras foram consideradas heréticas pela antiga Igreja. Entre os escritos que se aproximam aos últimos decênios do século I, e passando ao século II, encontram-se a primeira carta de Clemente, a Didaqué (que a partir de 1883 começou a fazer parte das edições dos Padres Apostólicos), talvez a carta de Barnabé, as cartas de Ignácio de Antioquia, os fragmentos de Papias, a segunda carta de Clemente, uma parte da 
carta de Policarpo e o martírio de Policarpo e o Pastor de Hermas (KÖESTER, 1988 p. 508).

Nas Coleções maniqueias e gnósticas, incluem-se grandes coleções de escritos, nas quais também estavam presentes obras canônicas e apócrifas em sua primeira coleção e, na segunda, a biblioteca de Nag Hammadi. Dessas coleções, conservaram-se na Ásia central numerosos fragmentos em turco, iraniano e chinês; como também no alto Egito foi encontrada uma biblioteca maniqueia em língua copta. A obra dessas coleções que mais exerceu influência no ocidente é a de "Atos apócrifos dos apóstolos”. Em 1945, no alto Egito (Nag Hammadi) foi descoberta uma coleção gnóstica de escritos. Segundo Köester (1988, p. 508-509), é uma biblioteca de treze volumes em copta que são, em sua maioria, traduções de escritos gregos, muitos deles anteriores ou pertencentes ao século II d.C.

A totalidade do corpus apócrifo neotestamentário forma uma coleção de escritos do Cristianismo primitivo que foi recopilado após a Idade Moderna e feita chegar até nós por caminhos diversificados e, às vezes, de forma fragmentada, apesar de alguns fragmentos já terem sido citados pelos padres da Igreja. Presumivelmente, os escritos apócrifos situam-se entre o final do século I d.C. e o século II d.C. Sendo assim, por se situarem no início do Cristianismo, os escritos apócrifos neotestamentários constituem uma importante fonte aos escritos canônicos para a história do Cristianismo primitivo. Tais escritos nos proporcionam uma visão muito mais ampla das tradições do nascimento do Cristianismo e nos permite uma grande variedade na perspectiva da teologia cristã em seu período primitivo (KÖESTER, p. 509-510).

Quanto aos testemunhos não cristãos do início do Cristianismo, são escassas as fontes. Encontramos algo sobre Jesus no historiador judeu Flávio Josefo (Ant. 18,63). Os primeiros testemunhos romanos procedem de Suetônio e Tácito. Suetônio (Vita Claudii 25,4) apresenta uma notícia a respeito da expulsão dos judeus de Roma, na época do reinado de Cláudio. A possibilidade que se tratara dos 
“cristãos” fica em aberto. Tácito (Annales 15,44, 2-8) faz referência mais detalhada aos cristãos que foram julgados por Nero de maneira cruel, devido a seu ódio à humanidade. Dión Casio (Epítome 67,14) faz referência à perseguição de cristãos no período de Domiciano, relatada na primeira carta de Clemente. Plínio, o Jovem (112 d.C., governador de Bitínia em Ásia Menor), em uma carta ao imperador Trajano, pedia conselho de como tratar e proceder contra os cristãos, pois 'os cristãos se reuniam em determinados dias, adoravam a Cristo, se comprometiam e depois se encontravam para celebrar uma comida comum'. Escritores pagãos como Luciano de Samosata (livro sobre o pseudoprofeta Alexandro) e o imperador Marco Aurélio (Meditações) situam-se a partir do século II d.C. com notícias sobre o Cristianismo (KÖESTER, p. 510-511).

Alta estima e consideração existiam no Cristianismo primitivo a respeito da Primeira Carta de Clemente e isso está presente, sobretudo, "no fato de que ela fosse temporalmente uma parte integrante do cânon neotestamentário nas igrejas egípcias e siríacas” (VIELHAUER, 1991, p. 548).

Convém mencionar que não há unanimidade entre os autores a respeito do lugar da composição da carta de Barnabé. Existem ainda muitas discussões a respeito do tema. Contudo, "se propõem a Alexandria, pelo método exegético que emprega o autor e que evoca a Filón, como a afirmação de 9,6 de que 'estão circuncidados todos os sírios, árabes e todos os sacerdotes dos ídolos', assim como os egípcios" (VIELHAUER, 1991, p. 634).

Os escritos apócrifos como o "O Evangelho dos Egípcios" e o "Evangelho dos Hebreus" apontam o Egito como o "lugar de sua origem". Philipp Vielhauer, citando W. Bauer (O.c., 54s.), diz que este

realçou a probabilidade de que as duas designações (Evangelho dos Hebreus e Evangelho dos Egípcios) estiveram destinadas a diferenciar os evangelhos de duas comunidades que viviam num mesmo âmbito (Egito); o Evangelho dos Egípcios seria o evangelho dos cristãos egípcios; o Evangelho dos Hebreus seria o evangelho dos judeu-cristãos do mesmo 
país. Se o Evangelho dos Hebreus recebeu esta denominação no Egito, é possível que, além do âmbito de uso, o Egito fosse também o lugar de origem do livro (VIELHAUER, 1991, p. 690).

O que nos interessa em relação à biblioteca de Nag Hammadi é a constatação da presença dessas literaturas em geografias tão próximas às terras africanas, isto é, no Egito. É edificante a suposição deste autor em apontar o Egito no século II d.C. como receptor do Evangelho de Tomé.

Os dados da tradição fazem supor que o Evangelho de Tomé se escreveu a meados do século II d.C. em Síria oriental; que chegou ao Egito no mesmo século e foi traduzido ali no século III; e que encontrou uma grande acolhida e alcançou uma grande difusão (VIELHAUER, 1991,p. 650).

Esta suposição torna-se fundamental e é confirmada pelas descobertas dos treze códices coptos em 1945 em Nag Hammadi (alto Egito). Jorge Pixley, referindo-se ao Egito diz: "Egito, o mais misterioso de todos os lugares onde se estendeu o movimento de Jesus. Egito dual, helênico e copta, com um cristianismo também dual" (PIXLEY, 1998, p. 8).

\section{Matizes históricos}

A existência do Cristianismo como uma experiência mais ou menos sistematizada, encontrá-la-emos atestada por muitos dos historiadores a partir dos séculos II e III. Porém, encontramos o Cristianismo como uma experiência germinal desde o início da "divulgação da Boa Nova”, isto é, em meados do século I. Essa possibilidade, de antemão, Marcel Simon e André Benoit a confirmam, quando dizem que:

embora não seja impossível que certas regiões mais ocidentais como o litoral mediterrâneo da Gália ou, com maior probabilidade, Cartago e a costa setentrional da África, tivessem recebido missionários cristãos antes de encerrar-se o século I, a existência de Igrejas na Gália e na África só é atestada na segunda metade do século II" (SIMON; BENOIT, 1987, p. 114). 


\title{
Ainda segundo Edward Ullendorff,
}

muito foram apreciadas aquelas formas de Judaísmo e Cristianismo que foram fundados no sul-ocidente de Arábia, onde não apenas eram imbuídos com uma marca das cerimônias orientais, mas com suas características semíticas, como as circunstâncias de seu desenvolvimento, como suas religiões, histórias e atmosfera emocional... (ULLENFORFF, 1968, p. 22).

Tomás Kraft e John Baur oferecem algumas informações sobre o período de 138-220 d.C. aproximadamente, nos quais apresentam alguns centros dessa época e personagens destacados; entre eles, alguns mártires cristãos que, em uma cronologia relativamente próxima ao período germinal do Cristianismo, apresentam fortes convicções e solidez. Entre os grandes centros dessa época, temos:

\begin{abstract}
Alexandria e Cartago, com grupos de mártires em ambos os lugares. Os personagens mais destacados da ortodoxia cristã nessa época são Agripa Castor, Panteno, Clemente Alexandrino, Origens e Tertuliano, em Cartago. Entre os heterodoxos, temos os marcionitas Apeles, em Alexandria, Hermógenes, em Cartago, e Quintilha da seita de Caio, também em Cartago. Entre as obras desta época, encontram-se os grandes tratados de Tertuliano, Clemente de Alexandria e Origens (KRAFT, 1998, p. 172).

Houve muitos outros mártires africanos nesses tempos iniciais, sendo famosas entre eles duas mulheres, Felicidade e Perpétua, mencionadas no cânon romano de missa. Felicidade era uma jovem escrava africana que trouxe para a fé a sua senhora Perpétua. A narrativa, com os seus numerosos nomes originais africanos, dá credibilidade a tese de que, na África, como em outros lugares, o Cristianismo originariamente se sentia mais à vontade entre as classes baixas da sociedade, embora mais tarde a igreja oficial tenha estabelecido as suas fortalezas entre a gente rica (BAUR, 2002, p. 21).
\end{abstract}

Observamos que na historiografia neotestamentária, é considerável e fundamental a presença de escolas e personagens que propiciaram, num horizonte mais amplo do Cristianismo (séculos II e III d.C.), escritos, relatos e testemunhos que expressaram o pensamento e a cosmovisão de experiências cristãs vivenciadas ao longo da história e de distintas geografias, com variadas interpretações. Alguns figuram na "lista dos padres da Igreja" e outros estão presentes na memória da história da literatura cristã primitiva. No Egito, foi significativa a "Escola de 
Alexandria", assim como também de personagens como "Clemente de Alexandria, Orígenes, Dionísio de Alexandria, Pierio, Pedro de Alexandria, Hesíquio, entre outros" (QUASTEN, 1968, p. 317-426). Na África cristã, "o mais antigo documento latino de que se tem noticia corresponde às 'Atas dos mártires Scilitanos [cf. p. 180]" (QUASTEN, 1968, p. 544-546); assim como se destacam os personagens "Tertuliano" (QUASTEN, 1968, p. 546-635), "Cipriano, Arnóbio e Lactâncio" (QUASTEN, 1968, p. 636-702). Na Líbia, encontra-se "Arrio (256-336), formado em Antioquia e destinado à Alexandria" (QUASTEN, 1973, p. 10-16).

Na compreensão de Pierluigi Piovanelli (2005, p. 37), a mitologia cristã pode ser descrita como um conjunto de todas aquelas tradições que, em geral, foram preservadas pelos textos canônicos, como também pelos textos apócrifos. O conjunto dessas tradições memoriais tem a função de proporcionar uma memória coletiva de uma representação ou de uma série de representações a respeito da origem de certa comunidade. Os textos canônicos e apócrifos, juntos, formam um conjunto de tradições sobre a origem da religião cristã e das comunidades, tendo em comum a fé em um mesmo indivíduo: Jesus Cristo. Algumas dessas tradições memoriais cristalizadas nas formas aparecem como textos canônicos e outras tradições ficam abertas aos sujeitos com contínuas variações, produzindo os textos apócrifos. Porém, todos juntos são dedicados à transmissão da tradição memorial sobre as origens.

De acordo com Piovanelli (2005, p. 40), em se tratando dos textos apócrifos, estes instruem o leitor para o tratamento com os textos antigos, a apreciá-los como uma contribuição original e que pode levar ao conhecimento não apenas do Cristianismo primitivo, mas também das sociedades e das culturas que produziram e produzem tais textos. Portanto, o estudo dos textos apócrifos como narrativas sagradas se torna uma valiosa ferramenta metodológica de profunda relevância para a pesquisa do Cristianismo Primitivo enquanto linguagem religiosa, definido e incorporado no conjunto das diferentes metodologias com força de equivalência e de complementaridade, firmado pelo seu caráter literário de gênero exótico e de 
diferenciação. É nesse contexto que, de modo peculiar, situamos a obra de Atos Apócrifos de André, que se constitui no exercício da memória e que gera sentidos para as comunidades cristãs primitivas.

\section{Atos apócrifos de André: informações preliminares e contribuições para a pesquisa do cristianismo primitivo}

O texto dos Atos Apócrifos de André aqui mencionado é da edição crítica bilingue (grego-Espanhol), preparada por Antonio Piñero e Gonzalo Del Cerro (2004, p. 157-235), que corresponde aos capítulos 1-50 (Martírio do Santo e ilustre Protócleto André Apóstolo) e 51-65 (Martírio de Santo André, Apóstolo e protócleto). A primeira parte (cap. 1-50) refere-se à chegada de Estratocles a Patrassa, as curas e atos realizados pelo bem-aventurado André, os acontecimentos relacionados a Maximilia, Estratocles, Euclia, Efidama e Alcman, a prisão do bemaventurado André pelo impiedoso Egeates, as conversões realizadas por André e os discursos do mesmo na prisão. A segunda parte (cap. 51-65) refere-se ao martírio de André da prisão à cruz, culminando com a morte e sepultura do apóstolo e a plegária final do autor.

Existe escassez do material autêntico e original dos Atos Apócrifos de André. Isso se deve às numerosas reelaborações que a tradição sofreu. Porém, segundo Antonio Piñero e Gonzalo del Cerro,

as lendas e tradições sobre o apóstolo André são talvez mais variadas e numerosas que as de nenhum outro dos apóstolos. André foi, com efeito, o primeiro dos apóstolos que foi chamado por Jesus ao apostolado (Jo 1,3539). André ocupa na lista dos apóstolos um lugar de privilégio (Mt 20,2-4; Lc 6,13-16; Mc 3,16-19 e Atos 1,13). (PIÑERO; DEL CERRO, 2004, p. 109) 
Mesmo com a escassez das fontes originárias e autênticas, alguns autores (PIÑERO; DEL CERRO, 2004, p. 110-111)² trataram de empreender um importante caminho de reconstrução dos textos originais dos Atos Apócrifos de André.

Pela amplitude e diversidade da literatura intertestamentária, não estaria bem afirmar que Atos Apócrifos de André se tratasse de um único e determinante gênero literário. Também não estaria bem convencionar opiniões de que sempre uma única fonte literária determina absolutamente a origem de uma obra. Omitimos, desse modo, a possibilidade da dinâmica e fluidez presentes no processo da construção dos referidos gêneros. Assim, faz-se importante reconhecer como fonte literária dos Atos de André não somente os Atos canônicos de Lucas, como também os gêneros literários que permeiam a vasta literatura novelística e historiográfica greco-romana.

Para Piñero e Del Cerro (2004, p. 126), os Atos apócrifos de André participam claramente do caráter geral do livro canônico dos Atos de Lucas: missão e dispersão dos apóstolos, viagens missionárias, pregações, milagres. Outros autores, como James Montague Rhodes (1955, p. 338-362), também apresentam outros elementos constitutivos da obra Atos apócrifos de André, que comumente são encontrados na obra lucana canônica de Atos dos Apóstolos, como por exemplo: enfrentamento de André com os filósofos, batismo, ofertas cedidas logo depois dos milagres e a não aceitação das mesmas por André, este ser acusado por falar contra o templo e as antigas leis em Tessalônica, o nome de Deus (Senhor, Jesus Cristo).

Para Piñero e Del Cerro (2004, p. 126-133), conter aspectos que lembram novelas helenísticas, vidas de personagens ilustres ou elogios de filósofos não

\footnotetext{
2.“J. M. Prieur: coleção Corpus Christianorum de Brepols; J. Flamion: Les Actes primitifs d'André d'aprés les textos; M. Bonnet coloca como base o códice V 808 (peri imaz): um dos fragmentos mais típico e importante dos atos primitivos; M. Erbetta, que oferece todos estes textos e referencias de outros menos significativos, como a Vida de André por Epifânio o Monje e tradução completa das Virtutes Andreae, de Gregório de Tours; M. Hornschih, em Hennecke-Schneemelcher de 1964, escolhe a opção de selecionar dois distintos fragmentos daquelas partes que considera autêntica. Assim o faz depois dos textos do papiro copta de Utrecht e do códice $V 808$ na parte que se denomina Texto reconstruido do martírio. Serve-se de diversos fragmentos dos martirios I e II, da Narratio, a Laudatio e a Epistola grega.
}

Horizonte, Belo Horizonte, v. 14, n. 42, p. 262-283, abr./jun. 2016 - ISSN 2175-5841 
depõe contra a apreciação geral de sua conexão com a escritura e concretamente com o livro dos Atos canônicos. Há também uma substancial diferença de qualidade e até de intenção entre os Atos apócrifos e os Atos de Lucas. Estes têm como finalidade demonstrar o cumprimento da promessa feita por Jesus e recolhida por Lc em Atos 1,8: 'Sereis meus testemunhos em Jerusalém e em toda a Judéia e Samaria e até os confins da terra', enquanto que nos Atos apócrifos de André a pessoa do herói ocupa um primeiro plano. É como uma novela religiosa, uma novela cristã, apresentando um caráter retórico evidente, mais visível nas passagens oratórias e, em particular, nas numerosas e longas plegárias colocadas na boca de seu protagonista. Em conclusão, ainda que os Atos de André possam ter como modelo básico os Atos canônicos dos Apóstolos, isso não significa dizer que seu autor não cedeu a seus próprios critérios pessoais e às influencias literárias da época (novelística grega - pensamento e letra dos escritos canônicos cristãos).

Quanto à autoria, data e lugar dos escritos dos Atos apócrifos de André, não existe um consenso. Cabe pensar em um cristão cultivado na língua grega, influenciado nas ideias cristãs como autor dos Atos de André, que teria escrito aproximadamente entre os anos 150 a 200 d.C. em Patrassa, na província de Acaia (Grécia). Patrassa é considerado o lugar dos últimos sucessos na vida de André, assim como seu martírio e sua tumba (PIÑERO; DEL CERRO, 2004, p. 141-144).

O gênero literário da obra dos Atos apócrifos de André está impregnado pelo seu entorno sócio-político-cultural. Nisso, tornam-se notórias as ações de rebeldia do bem-aventurado André contra a postura arrogante e prepotente da autoridade de Acáia (Grecia), e sua benevolência aos que são curados e exorcizados em nome de Jesus Cristo. São ações que estão molduradas pelo contexto das literaturas greco-romanas da época, com forte influência da filosofia platônica, gnosticismo e dos pensamentos e escritos cristãos. Assim, 
o tema central dos Atos de André é o movimento para o mundo cujas características são transitórias e ilusões, multiplicidades e movimentos, e a realização verdadeira do ser está no retorno ao UNO, isto é, a Deus. Esta concepção corresponde exatamente ao Platonismo do meio período, para o qual todo o movimento filosófico do autor estava próximo. (HORNSCHUH, 1975, p. 393-395).

\section{Para Piñero e Del Cerro,}

existe uma série de conflitos muito marcados, como o 'antes' e o 'agora'; o 'tempo dos falsos deuses' e o 'homem novo renovado'; a 'escuridão' cede lugar à 'luz'; as 'potências maléficas' cedem lugar aos 'dons de Deus'; o 'cristão' 'pertence à transcendência' e está sobre a matéria, o tempo, o movimento; o homem é 'cativo do corpo' e a morte causa sua separação, isto é, 'corpo e alma'; preferir o amor de Deus que a hipocrisias das falsas filosofias e ensinamentos; preferir o homem interior que sua aparência (PIÑERO; DEL CERRO, 2004, p. 136-137).

A forte tendência encrática (PIÑERO; DEL CERRO, 2004, p. 138)3 nos Atos apócrifos de André, não entrando em nenhum pré-julgamento atitudinal, observase na conversão e postura de Maximila diante de seu esposo Egeates:

O amor pela vida de castidade perfeita é em Maximila tão exagerado que 'querendo viver castamente', não tem dificuldades em provocar uma situação tão irregular como a de utilizar sua escrava Euclia para que a substitua em suas obrigações conjugais" (PIÑERO, DEL CERRO, 2004, p. 138).

Porém, essa atitude de Maximila não pode ser generalizada como o "senso comum" de todos os (as) convertidos (as), e sim como uma opção vivida em circunstâncias especiais.

Maximila, junto a Estrátocles tornam-se exemplos de conversão e aceitação da mensagem da salvação que, confessando um só Deus, aderiram ao caminho proposto pelo apóstolo André, que culminaria em um lugar preparado pelo apóstolo, isto é, a Pátria celestial.

\footnotetext{
3. "A tendência encrática tem seu fundamento na concepção, ortodoxa, porém inspirada no gnosticismo, da consubstancialidade do espírito com a divindade e da pertencia do corpo ao diabo (demiurgo)".
}

Horizonte, Belo Horizonte, v. 14, n. 42, p. 262-283, abr./jun. 2016 - ISSN 2175-5841 
A morte nos Atos apócrifos de André torna-se uma libertação do corpo para o "voo até nossa pátria” (PIÑERO; DEL CERRO, 2004, p. 213), pois, 'a morte não é o fim desta vida passageira'. Confirma-se, assim, a convicção do apóstolo no caráter salvífico do querigma cristão, por ele anunciado. Sendo assim, a cruz, a dor, a prisão e a morte do apóstolo André são situações equivalentes à vida e morte de Jesus Cristo, com a qual ele se identifica, confia e promete aos seus seguidores.

A veneração à cruz pelo apóstolo André é um dos momentos cruciais de sua vida. É como uma aproximação ao 'mistério salvífico de Deus', onde une sua vida em Deus na plena comunhão com a comunidade. Assim como Jesus, no evangelho canônico (Mt 27,59-60), é tirado da cruz, cuidado e sepultado por José de Arimatéia, também André, seu discípulo, é desamarrado da cruz, cuidado e sepultado pelos seus discípulos Maximila e Estratocles.

A morte suicida de Egeates confirma a atitude encrática de Maximila na fidelidade e perseverança aos ensinamentos do bem aventurado André. O destino trágico de Egeates é a consumação das admoestações e exortações feitas por André na cruz ao longo de três dias e três noites às mulheres, crianças, anciãos, escravos e livres. Deve-se aniquilar a 'corrupção' do corpo, a aparência, presunção, prazeres, crimes, paixões, adultérios e exaltar o caminho do discipulado dotado de fé e de amizade com Deus. Egeates é 'deixado ser o que é' a partir daquilo que ele mesmo ignora de seu 'ser', enquanto André e seus discípulos (as) irão ao 'que é deles', ao eterno, ao invisível, ao uno, a Deus. Como caminho da comunidade cristã em Acáia, Maximila escolheu uma vida casta e tranquila, não aceitando Egeates, guiada pelo amor de Cristo.

A missão itinerante do bem-aventurado apóstolo André é caracterizada por grandes prodígios (discursos, apologias, milagres, curas, conversões, etc.), como o observamos na obra lucana de Atos dos apóstolos; porém, com forte ênfase à 'pessoa de André', próprio da novelística grega dos grandes heróis. Nessa missão também se enfatiza a elevação do ser humano além de sua corporeidade, isto é, a 
superação da vida penosa, presunção, vazio, corrupção, cólera, crimes, inimizades, paixões, adultérios, à uma vida que vai mais longe que a palavra, que o corpo, que a lei, que o tempo, que os prazeres amargos e ímpios. Nisso consiste as características de formoso, melhor, justo, misericordioso, luz atribuídas por André aos que pertencem ao Uno, a Deus, em oposição às forças punitivas, aos poderes maus, aos arcontes terríveis, aos anjos de fogo, aos demônios feios e às energias impuras que não pertencem ao sinal do selo. Eles fugirão correndo e se refugiarão na escuridão, no fogo.

Os Atos apócrifos de André nos possibilitam visualizar a vasta literatura no contexto do Cristianismo primitivo. São escritos sagrados, resultados dos exercícios hermenêuticos e das releituras de experiências religiosas vividas no percurso da história, presentes na memória individual e coletiva do povo e das culturas antigas. Certamente, na memória das comunidades cristãs primitivas dos séculos I ao III d.C, estiveram presentes muitas e variadas experiências cristãs que são contempladas na redação da literatura neotestamentária, nos diferentes gêneros literários e nas diversas formas de construções das narrativas e das linguagens, que foram construindo as identidades religiosas.

\section{As narrativas apócrifas e linguagem religiosa na perspectiva das novas abordagens das teorias da linguagem}

Para Astrid Erll e Nunning Ansgar (2008, p. 1), a relação entre cultura e memória emerge em muitas partes do mundo como uma chave da pesquisa interdisciplinar, envolvendo campos diversos como a história, a sociologia, a arte, a literatura, a filosofia, a teologia, a psicologia e as neurociências, levando, desse modo, a humanidade aos estudos sociais e às ciências naturais em um único caminho. A importância da noção de memória cultural não é apenas por esta ser documentada em um rápido desenvolvimento desde 1980 em publicações de memórias de famílias, de religião e de memória social e nacional, mas também pela 
recente tendência de empreender uma visão do estado da arte emergindo nesse campo e pela síntese de diferentes tradições no campo da pesquisa. Memória cultural é certamente uma noção variada, um termo usado em ambíguos e vagos caminhos. Meios, práticas e estruturas diversas como os mitos, os monumentos, a historiografia, o ritual, as lembranças convencionais, a configuração do conhecimento cultural e a rede neuronal estão atualmente sob a amplidão desse conceito.

Jan Assmann e John Czaplicka (1995, p. 126-127) estabelecem duas definiçõos de memória cultural. A primeira diz respeito à memória comunicativa, em que se incluem aquelas variedades de memórias coletivas que estão baseadas exclusivamente na comunicação cotidiana, caracterizadas pelo forte grau de não especialização, reciprocidade de papéis, instabilidade temática e desorganização e que constituem um estágio de transição entre cotidiano e comunicação cultural. Por meio dessa comunicação, cada indivíduo compõe uma memória que é socialmente mediada e relatada para um grupo. A memória individual é constitutiva da comunicação com os demais. Esse "outro" não é apenas qualquer pessoa, mas antes, eles são grupos que concebem sua unidade e peculiaridade através de uma imagem comum de seu passado, como a família, os vizinhos, grupos de profissionais, partidos políticos, associações e nações. Cada indivíduo pertence aos numerosos grupos e, consequentemente, acolhe numerosas autoimagens e memórias.

A segunda definição, ainda de acordo com Assmann e Czaplicka (1995, p. 129), diz respeito à distância do cotidiano. Enquanto a memória comunicativa está caracterizada pela proximidade com o cotidiano, a memória cultural está caracterizada pela distância. A distância do cotidiano marca o horizonte temporal. A memória cultural tem um ponto fixado e esse horizonte não muda com o passar do tempo. Esses pontos fixados são determinados pelos eventos do passado, em que a memória é mantida por meio da formação cultural (textos, ritos, monumentos) e comunicação institucional (recitação, práticas, observância, etc.). 
No fluxo da comunicação cotidiana, cada festival, ritos, poemas, imagem, etc., formam "ilhas de tempos", ilhas de uma temporalidade completamente diferente e suspensa do tempo. Na memória cultural, cada ilha de tempo expande na memória os espaços de contemplatividade/meditação retrospectiva. Desse modo, tal compreensão estabelece a pertinência ao conjunto da dinâmica dos diferentes grupos étnicos e religiosos que constituíam as comunidades cristãs primitivas, onde, certamente, faziam memória do acontecimento crístico por meio de testemunhos, da oralidade, da proximidade e do distanciamento do cotidiano, das representações simbólicas, da linguagem e dos textos escritos e interpretados.

Jan Assmann (2011, p. 15-69) sugere a compreensão de "cultura da memória" para o constructo "memory culture" e, desse modo, relaciona essa ideia aos grupos e às obrigações sociais, sendo a memória um importante componente para a formação da comunidade, favorecendo a construção da identidade dos grupos.

Assim mesmo, faz-se necessário reconhecer também como fonte literária dos Atos de André os gêneros literários que permeiam a vasta literatura novelesca e historiográfica greco-romana. Pela narrativa, pela linguagem, pelo discurso e pela força do seu enredo vai sendo gerada uma nova e diferente face da identidade cristã nos cristianismos dos primeiros séculos e com ênfase no posicionamento de crítica social.

Enquanto crítica social nas narrativas cristãs apócrifas, Judith Perkins (2009, p. 95) sustenta que a crítica ao sistema de justiça é inerente aos Atos dos Mártires e ao discurso da ressurreição material. Os textos cristãos encorajavam seus seguidores, recusando as demandas judiciais romanas e projetando uma futura corte de direito celestial o que, além disso, registra um descontentamento com os arranjos legais da contemporaneidade. Esses textos conformam a premissa de que o sistema de justiça e as cortes/fóruns e seus procedimentos são falhos e injustos. Os textos cristãos se apresentam como discurso social em torno da corte e 
da justiça nesse período. O contexto judicial do antigo império romano ajuda a compreender a ênfase que se dá à ressurreição do corpo material nos referidos textos, conectando a ressurreição material com o julgamento que deve ser digno de atenção.

Desse modo, os Atos Apócrifos de André, por meio do conjunto das narrativas e dos discursos religiosos, do seu enredo e das representações simbólicas forjadas pelo exercício da memória individual e coletiva, nos permitem a compreensão do ideal do martírio e da conduta e atitudes de seus personagens como reconstrução da cosmovisão sociocultural e política dos grupos de cristãos, sugerindo uma forte crítica social. Para Perkins (2009, p. 97), os cidadãos livres de baixo status e os escravos conformam um agregado social isolado. Os grupos são controlados pelo medo e pelo temor. Augusto depreciava tais grupos. No antigo império romano, os cidadãos, em contraste com os escravos, não estavam propensos aos tratamentos violentos. Augusto dividia a comunidade cívica ao longo de uma nova linha de fronteira baseada no status de posses ou de carência das posses dos privilégios civis. Portanto, continua Perkins (2009, p. 101-102), os corpos são humilhados, desonrados, degradados. As pessoas são legalmente vulneráveis pela humilhação e pela violência, contribuindo para o enfraquecimento social. Os textos cristãos contestam essa perspectiva. Tal contestação tem ramificação tanto religiosa como também social. $\mathrm{O}$ discurso religioso interrompe a base do desprezo corpóreo. O corpo humano de Jesus refigura o corpo material humano numa associação plena do ser humano. A reabilitação do corpo tem relevância para as pessoas nessa perspectiva do ser humano. Corpo e sociedade, a sociedade em tensão. Corpo e sociedade se rompem e se reconfiguram e, então, surgem as representações grotescas nas narrativas de gêneros exóticos.

Nos Atos Apócrifos de André, o discurso de André na narrativa sugere um distanciamento do "mundo real" para um "mundo idealizado", mas que o contempla e onde se supõe uma crítica social em um contexto cultural definido, 
em que se apresenta uma inversão de valores na sociedade da Acáia. Assim, “o discurso das culturas não representa o mundo "real”, mas um mundo mediatizado através de categorias sociais, relações e instituições operando numa cultura específica”. (PERKINS, 1995, p. 3) Wolfgang Iser (2013, p. 939) sugere que a obra literária excede o mundo real que ele incorpora. Consequentemente, não é surpresa que a ficção literária frequentemente tenha sido estigmatizada como falsidade. A partir dos discursos de que o mundo real não existe, se apresenta a ideia de que tudo é irreal e não existe.

Ficção e ficcionalização, segundo Iser (2013, p. 939-940), vinculam uma dualidade e a natureza dessa duplicidade dependerá do contexto: falsidade e literatura são diferentes e produtos do processo da duplicação. Visto que essa dualidade precede a forma de realização, as fronteiras que se cruzam podem ser visualizadas como um carimbo da ficcionalização. A falsidade esconde a verdade, mas a verdade está potencialmente na máscara que a dissimula. Na ficção literária, a existência dos mundos é excedida e eles são individualmente reconhecidos. A falsidade e a literatura também contêm dois mundos. A falsidade incorpora a verdade com a intenção de que esta seja ocultada. A ficção literária incorpora uma realidade identificável, com uma moldura imprevisível. E é por isso que descrevemos a ficcionalização como um ato de "excesso". Nós devemos conceber que a realidade excessiva permanece no presente, imbuindo a ficção com a dualidade que pode ser explorada por diferentes propósitos, possibilitando ao leitor a oportunidade de diferentes releituras e de recriações dos textos e das narrativas por meio do exercício da arte da imaginação.

Ute E. Eissen (2010, p. 215-217), em seu artigo "Fiction and imagination in early Christian literature: the acts of the apostles as a test case” considera que até recentemente, a categorias crítica literária de ficção e ficcionalização tinha sido pouco usado na pesquisa do Novo Testamento e, mesmo assim, com muita cautela. As definições desse conceito no debate crítico literário são muitas e ocasionalmente completas de contradições, criando uma extensa discussão. Ficção significaria, de 
forma geral, a “criação, composição”. É um constructo. Em recente pesquisa crítica histórica e literária, o campo semântico da ficção tem aumentado, sendo movido mais além da literatura imaginada, se estendendo especialmente para as narrativas historiográficas. Os principais autores vêm adotando uma tendência bem clara, como Hayden White no contexto anglo americano, Paul Ricouer na França e Arnaldo Momigliano na Itália.

Novas oportunidades de diferentes releituras e de recriações dos textos continuam aparecendo nos enredos das narrativas apócrifas no período helenístico tardio e no Império Romano primitivo, como é o caso do tema "sofrimento do corpo" nas literaturas e narrativas de martírios, como é o caso de André, nos Atos Apócrifos de André. De acordo com Judith Perkins (1995, p. 3-7), temas como o sofrimento do corpo veio a ser um foco de significado cultural e cria uma nova subjetividade - o eu como sofredor. Uma chave para o sucesso do Cristianismo foi a habilidade para produzir um gênero de temas necessários para formar a base da unidade social e política.

Tal modelo de discipulado, no que concerne aos Atos Apócrifos de André, consolidado por representações femininas e masculinas, vinculado a Cristo Jesus e voltado à subjetividade humana, pela força do discurso e das narrativas construídas pelo exercício da memória cultural, por meio das representações simbólicas e da ficção literária, desenvolvido em forma de enredos configuraria uma recriação das identidades religiosas no Cristianismo primitivo, relido e recriado por um peculiar auditório a esse gênero.

Yuri M. Lotman (1996, p 52-56), satisfatoriamente, apresenta grandes contribuições para os estudos narratológicos e para as novas abordagens dos conceitos das teorias da linguagem, como o capítulo sobre A Teoria Semiótica da Cultura (Universe of the Mind, 1990) e o capítulo La Semiótica de la Cultura y el Concepto del Texto (La Semiosfera, 1996) para uma melhor compreensão do exercício das releituras e de recriação dos textos e das narrativas. Lotman sugere 
que o texto se apresenta diante de nós como um complexo dispositivo que guarda variados códigos, capaz de transformar as mensagens recebidas e de gerar novas mensagens. É como um gerador informacional que possui as características de uma pessoa com um intelecto altamente desenvolvido. Nesse sentido, muda a ideia que se tinha a respeito da relação entre o consumidor e o texto. Ao invés de dizer que o consumidor decifra o texto, é possível dizer que o consumidor trata com o texto. Entra em contato com o texto. O processo de decifrar o texto se complica de maneira extraordinária, pois perde o seu caráter de acontecimento finito que acontece uma só vez, se tornando um trato semiótico de um ser humano com outra pessoa autônoma.

Para Lotman (1996, p. 52-56), é evidente que somente o texto não pode gerar tal sentido e por isso deve entrar em relação com o auditório para que se realizem suas possibilidades gerais. Para isso, o texto deve estar submerso na semiosfera e isso significa uma situação paradoxal, pois deve acontecer um contato com outros textos. Assim, de maneira análoga, poderíamos falar que o contato com outra cultura desempenha o papel de um mecanismo de arranque, que coloca em marcha os processos geradores. A memória do homem que entra em contato com o texto pode ser considerada como um texto complexo, o contato com o qual conduz a mudanças criadoras na cadeia informacional.

\section{Considerações finais}

Desse modo, os conceitos oriundos das teorias da linguagem permanecem vigentes como um material pedagógico e metodológico de análise narratológica, em que "um texto" poderá ser interpretado com diferentes significados e compreendido a partir das diferentes experiências e perspectivas individuais, coletivas e socioculturais, numa dinâmica plural dos diferentes grupos sociais, étnicos e religiosos. Portanto, as narrativas sagradas como texto literário são recriadas na relação que se estabelece entre o autor/leitor/auditório e, sobretudo, a 
narrativa. É o processo gerador dos textos e Atos Apócrifos de André se situa na dinâmica de recriação do auditório, de exercícios de memórias individuais e coletivas preservadas e ativadas pela linguagem, em narrativas ficcionais, dos diferentes grupos cristãos em seu processo interacional. É esse processo gerador dos textos que na sua produção de sentidos recriará as identidades e fixará as fronteiras que definirão os grupos e a autocompreensão sócio-religiosa e cultural do Cristianismo primitivo. Portanto, nisso irá consistir a necessidade e a importância dos estudos das narrativas apócrifas como linguagem religiosa, para a pesquisa do Cristianismo primitivo e sob a égide da teoria das linguagens.

\section{REFERÊNCIAS}

ASSMANN, Jan; CZAPLIKA, John. New German Critique, n. 65. Cultural

history/cultural studies. New German Critique - Stable URL. Spring - Summer, 1995.

ASSMANN, Jan. Cultural memory and early civilization. New York: Cambridge University Press, 2011.

BAUR, John. 2000 anos de Cristianismo em África: Uma História da Igreja Africana. Lisboa: Ed. Paulinas, 2002.

EISSEN, Ute E. Fiction and imagination in early Christian literature: the acts of the apostles as a test case, p. 215-217. In: LISS,Hanna; OEMING Manfred (ed.). Literary construction of identity in the ancient World. Winona Lake, Indiana: Eisenbrauns, 2010.

ERLL, Astrid; NUNNING Ansgar (ed.). Cultural Memory Studies: An International and Interdisciplinary Handbook. Berlin/New York: de Gruyter 2008.

HORNSCHUH, Manfred. apud E. Hennecke (edited by W. Schneemelcher), New Testament Apocrypha, London: SCM Press Ltda., vol. 2, 1975, p. 393-395.

ISER, Wolfgang. Fictionalizing: The Anthropological Dimension of Literary Fictions. New Literary History, Baltimore, v. 21, n. 4, p. 939, 1990. Disponível em: < http://www.jstor.org/stable/469193> Acesso em: 20/o6/2013

LOTMAN, Yuri M. La Semiosfera: Semiótica de la Cultura y del Texto. Tradução de Desiderio Navarro. Madrid: Ed. Cátedra, S. A., 1996.

LOTMAN, Iuri M. Universe of the mind: A Semiotic Theory of Culture, Bloomington: Indiana University Press, 2000. 
MARGUERAT, Daniel. A primeira História do Cristianismo: Os Atos dos Apóstolos. São Paulo: Paulus; Loyola, 2003.

KÖESTER, Helmut. Introducción al Nuevo testamento. Salamanca: Ediciones Sígueme, 1988.

KRAFT, Tomás. La Iglesia primitiva en África. In: Revista de Interpretación Bíblica Latino Americana (RIBLA), Petrópolis, n. 29, p. 172, 1998.

OTERO, Aurelio de Santos. Los Evangelios Apócrifos. Biblioteca de Autores Cristianos. Madrid: La Editorial Católica, S.A., 1963.

PERKINS, Judith. Roman Imperial Identities in the Early Christian Era. London and New York: Routledge - Taylor \& Francis Group, 2009.

PERKINS, Judith. The Suffering Self: Pain and Narrative Representation in the Early Christian Era. London and New York: Routledge, 1995.

PIÑERO, Antonio; DEL CERRO, Gonzalo. Hechos Apócrifos de los Apóstoles: Hechos de Andrés, Juan y Pedro. Madrid: Biblioteca de Autores Cristianos, 2004.

PIOVANELLI, Pierluigi. What is a christian apocryphat text and how does it work? Nederlands theologisch tijdschrift, Wageningen, v. 59, n.1, p.31-40, 2005.

PIXLEY, Jorge. Presentación. In: Revista de Interpretación Bíblica Latino Americana (RIBLA), Petrópolis, n. 29, p.8, 1998.

RODHES, James Montague. Apocryphal New Testament. Oxford: At the Claredon Press. University Press, 1955.

QUASTEN, Johannes. Patrologia I. Biblioteca de Autores Cristianos. Madrid: La Editorial Católica, S. A., 1968.

QUASTEN, Johannes. Patrologia II. Biblioteca de Autores Cristianos. Madrid: La Editorial Católica, S. A., 1973.

SCHNEEMELCHER, Wilhelm (ed.). New Testament Apocrypha, v.1. Philadelphia; Greak Britain: Westminster/John Knox Press; James Clarke \& Co., 1991.

SCHNEEMELCHER, Wilhelm (ed.). New Testament Apocrypha, v.2. Great Britain: SCM Press Ltd., 1975.

SIMON, Marcel; BENOIT, André. Judaísmo e Cristianismo antigo: de Antíoco Epifânio a Constantino. São Paulo: EDUSP, 1987.

ULLENFORFF, Edward. Ethiopia and the Bible. London: Oxford University Press, 1968.

VIELHAUER, Philipp. Historia de la Literatura Cristiana primitiva. Salamanca: Sígueme, 1991.

Horizonte, Belo Horizonte, v. 14, n. 42, p. 262-283, abr./jun. 2016 - ISSN 2175-5841 